\title{
Taking Deterrence Seriously: The Wide-Scope Deterrence Theory of Punishment
}

\section{Hsin-Wen Lee}

To cite this article: Hsin-Wen Lee (2017) Taking Deterrence Seriously: The WideScope Deterrence Theory of Punishment, Criminal Justice Ethics, 36:1, 2-24, DOI: 10.1080/0731129X.2017.1298879

To link to this article: http://dx.doi.org/10.1080/0731129X.2017.1298879

册 Published online: 19 Apr 2017.

5 Submit your article to this journal

Q View related articles $\sqsubset$

View Crossmark data \lceil 


\section{Taking Deterrence Seriously: The Wide-Scope Deterrence Theory of Punishment}

\section{HSIN-WEN LEE (1)*}

A deterrence theory of punishment holds that the institution of criminal punishment is morally justified because it serves to deter crime. Because the fear of external sanction is an important incentive in crime deterrence, the deterrence theory is often associated with the idea of severe, disproportionate punishment. An objection to this theory holds that hope of escape renders even the severest punishment inapt and irrelevant.

This article revisits the concept of deterrence and defend a more plausible deterrence theory of punishment-the wide-scope deterrence theory. The wide-scope theory holds that we must make the best use of all the deterrence tools available, including both external and internal sanctions. Drawing on insights from the early Confucian tradition, the article develops a deep deterrence theory, which holds that the most important deterrence tool involves internal, not external, sanction. It describes how internal sanctions deter potential offenses and why relevant policies need not conflict with liberalism's respect for neutrality.

Keywords: crime, punishment, deterrence, deep deterrence, self-respect, honor

The end of punishment, therefore, is no other than to prevent the criminal from doing further injury to society, and to prevent others from committing the like offence.

Cesare Beccaria, On Crimes and Punishment

A deterrence theory holds that criminal punishment is justified

${ }^{*}$ Hsin-wen Lee is an Assistant Professor in the Department of Philosophy, University of Delaware, Newark, DE, USA. Email: hwl@ude.edu because punishment reduces or deters crime. ${ }^{1}$ Because the fear of punishment is considered a major incentive in deterring crime, deterrence theories are often associated with the idea of severe, disproportionate punishment. This common understanding of deterrence theory is subject to several criticisms, an important one of which suggests that hope of escape renders even the severest punishment ineffectual. If this is true, then deterrence theories are inept and irrelevant. 
In this article, I revisit the concept of criminal deterrence and defend a more plausible deterrence theory of punishment-the wide-scope theory. To appreciate the wide scope of the new theory, we must first explicate the narrow scope of traditional theories. Traditional theories have a narrow scope because the only tool of deterrence they can offer is fear of punishment. This lack of resources in criminal deterrence is also the reason why traditional deterrence theories are shallow-they assume that only the fear of punishment deters human beings from committing criminal offenses. In other words, the shallow deterrence theory (hereafter the shallow theory) assumes that only prudential reasons can deter human beings from offending. However, human beings are capable of entertaining both prudential and non-prudential moral reasons. I argue that we can expand the scope of criminal deterrence by exploring other sources of reasons and values. Drawing on insights from early Confucianism, I develop a deterrence theory that is deep and use it to expand the scope of useful deterrents. A deep deterrence theory (hereafter the deep theory) holds that we may deter criminal offenses by appealing to a person's sense of honor and/or self-respect. Unlike the shallow theory that appeals to external sanctions only, the deep theory appeals to an internal sanction; namely, one's respect for others and/or a sense of self-respect. This type of deterrent is deep because the sanction comes from within, so that a person may not commit a crime even when she is sure that no external sanction will ensue. Those theorists who are committed to protecting rights and deterring crimes must make the best use of all the resources available, including both shallow and deep deterrents. In other words, a committed deterrence theorist will try to deter crime by offering both prudential and non-prudential moral reasons. This new deterrence theory has a wide scope because it invokes both shallow and deep reasons in its fight against crime.

In section I, I describe two important assumptions of standard deterrence theory, including the capacity assumption and the deterrence assumption. The former holds that offenders are rational agents capable of taking into consideration the consequences of their actions, while the latter suggests that the function of punishment is to give actual and potential offenders reasons against performing a criminal act. In section II, I analyze some important features of deterrence theory by examining these assumptions. According to the definition I describe in section I, criminal punishment is a means to deter crime, an instrumental conception of punishment that is compatible with different conceptions of crime (here defined as a public wrong). If punishment is a means, its use must be constrained by the end(s) it serves. In the case of a liberal society, the imposition of criminal punishment must be constrained by the state's objective of protecting the rights of citizens. In section III, I consider why, traditionally, the concept of deterrence is typically associated with the idea of punitive, external sanctions. I argue that the second, deterrence assumption, leads many theorists to believe that punishment must involve punitive, external sanction-because it is the easiest and probably the most reliable way to ensure that offenders will be deterred. In section IV, I analyze the limitations of standard deterrence theory. We can immediately infer the 
limitations of standard deterrence theory after understanding its two assumptions-for punishment to deter crime, both assumptions must be met. I then analyze in some detail the cases in which an offender is not deterred by the prospect of punishment and suggest that in those cases we may deter crime by adopting certain alternative measures, including the inclusion of moral education to create internal sanctions.

In section V, I describe the deep deterrence theory of punishment, a theory that holds that we may deter crime by offering moral reasons against criminal offense. The deep theory does not prioritize purely punitive forms of punishment; rather, it supports various educational and rehabilitative programs designed to help ex-offenders to renew them- selves and to build new ways of living that render criminal offenses undesirable. In section VI, I explain why a thoroughgoing deterrence theory must embrace both deep and shallow deterrents, with a preference for deep deterrents. In section VII, I consider the objection that the deep theory is incompatible with liberalism's respect for personal autonomy and state neutrality. Given that the deep theory allows the state government to offer moral reasons against criminal offense, doubt might arise with regard to whether relevant policies would constitute some form of paternalism and would disrespect the personal autonomy of offenders. I describe how a liberal society may engage in relevant policy reform in a way that respects the autonomy of potential and actual offenders.

\section{The Deterrence Theory-Two Assumptions}

A deterrence theory of punishment holds that the institution of criminal punishment is necessary or justified because punishment serves to deter crime. How does punishment deter crime? Presumably, upon learning the likely consequences of committing a crime, a potential offender might abandon his plan because he would like to avoid the bad consequences attached to the crime; namely, the punishment associated with the offense. For instance, if I know that the punishment for stealing a pizza is three months of prison time, I may not steal the pizza because I do not want to spend three months in prison.

From this brief description, we can observe two important assumptions of the deterrence theory: (1) potential offenders are rational agents capable of taking into consideration the likely consequences of their actions; and (2) punishment is intended to give potential offenders a reason not to commit a crime.

\section{i. Assumption (1) The Capacity Assumption-Potential Offenders Are Rational Agents}

Deterrence theory is commonly associated with the rational choice theory. It assumes that potential offenders are rational agents capable of taking into consideration the consequences of their actions. If an action $\mathrm{X}$ will (highly likely) bring about some undesirable consequence $\mathrm{Y}$, then rational 
agents will avoid doing $X$ because they would like to avoid Y. Thus, in criminal legislation, sanctions are attached to various criminal offenses. They are regarded as a negative consequence of criminal wrongdoing, a price to be paid for violating the criminal code. Because rational agents would like to avoid these bad consequences, they will likely avoid committing the offenses. This is how punishment deters crime. Without the capacity to consider and comprehend the consequences of one's actions, a person cannot be deterred by the threat of punishment.

Given that the first assumption focuses on the capacity of rational agents, I will call this assumption the capacity assumption. It is an assumption adopted by most people who support any system of criminal law and punishment, including both deterrence theorists and retributivists. Regardless of the theory of punishment one supports, one must make this assumption. Unless an agent has the capacity to consider the consequences of her actions, it is futile to talk about deterring crime or giving offenders what they deserve. If an agent does not have the necessary mental capacity, we cannot deter her by threatening her with a bad consequence. In this case, we cannot give her what she deserves either, because she lacks the capacity to be held responsible for the consequences of her actions. $^{2}$ The capacity assumption is commonly adopted by the criminal code in different societies; those who lack this capacity are typically exempted from criminal responsibility by the criminal law.

\section{ii. Assumption (2) The Deterrence Assumption-Punishment Aims to Give Reasons Against Criminal Offense}

Because punishment is supposed to dissuade rational agents from engaging in criminal activities, methods of punishment are likely to come in the form of some negative experience- a cost or a price, rather than a benefit or reward. If we are to deter rational agents from committing crimes, we must make sure that the consequences of offending are likely to be bad for them. Otherwise rational agents may go forward with their plan to commit a crime. In addition, if a form of punishment causes only mild damage to an offender, then the offender might consider this punishment an acceptable cost to his offending. When a method of punishment is not severe enough, potential offenders might think that overall, the consequences of committing a crime are still preferable to not committing it. Thus, in order to deter crime, punishment must function to make criminal offenses unprofitable and possibly also injurious to the interests of the offender. In this way, we can be sure that rational offenders will likely be dissuaded from offending.

Because the second assumption focuses on the instrumental function of punishment-namely, to deter crime-, I will call this assumption the deterrence assumption. This assumption tells us why we punish and what the point of punishment is. Next, I will analyze the implications of these assumptions for standard deterrence theory. 


\section{Why Punish?}

\section{i. The Instrumental Value of Punishment}

My argument in section I suggests that in a deterrence theory of punishment, punishment has instrumental value that is conditioned by serving the end of reducing the occurrence of criminal offenses. This position stands in contrast to retributivism, the theory that punishment has intrinsic value because punishment give offenders what they deserve or is required by standards of fairness. ${ }^{3}$ For example, prototype retributivists believe that punishment should be distributed according to an offender's moral desert. One way to determine that distribution is to apply the principle of lex talionis and impose some form of "mirror punishment" on the offender-for example, an eye for an eye, a tooth for a tooth. This prototype retributivist principle has certain inadequate public policy implications. A commonly cited one is that this principle requires that a rapist be punished by being raped. This prescription is problematic for a variety of reasons unrelated to the retributivist principle itself. If the rapist deserves to be raped, it is not clear how the state can adequately fulfill this demand, since it requires the state and/or the punisher to engage in activities that are considered to be morally problematic. Many retributivists believe that the problem can be fixed by replacing the principle of lex talionis with the principle of proportionate sentencing. Imprisonment thus becomes the currency with which we measure the severity and proportionality of punishment. Deprivation of liberty by imprisonment becomes the default form of punishment because it allows us to compare the prices that different offenders pay. Imprisonment becomes justified if the length of imprisonment reflects the ill moral desert of the offender. The value of imprisonment as a form of punishment is independent of its deterrent effect. Imprisonment as a form of punishment is intrinsically good if it is imposed on an offender according to her moral desert; it is morally justified because it is one way in which a government may give offenders what they morally deserve.

In contrast, according to deterrence theory, a form of punishment is justified by its deterrence value. Thus, if a method of punishment is expected to deter crime, then it has pro tanto positive value in proportion to the degree it deters crime. On the other hand, if a form of punishment did not deter crime, it has no deterrence value. Furthermore, if a form of punishment is likely to encourage more criminal offenses, then it has pro tanto negative value. Notice that the same form of punishment can have both positive and negative deterrence values. Consider the case of imprisonment. Imprisonment may have positive deterrence value because offenders may fear the loss of freedom of movement, so that the likelihood of imprisonment may deter those who do not want to be incarcerated. Further, imprisonment incapacitates those who are in prions and decreases their chances of reoffending, at least during the period of time when they are in prison. On the other hand, imprisonment may also 
have negative deterrence value. For instance, a thief may learn from her cellmate certain skills of stealing, or exchange experience on criminal defense in court. Having a criminal record may also make certain career options difficult or even impossible for an ex-offender. In this case, an offender may experience problems returning to the community and may feel that she has to resort to unlawful means to sustain her lifestyle. Imprisonment thus may have a negative deterrence effect and can actually lead to more crime.

Notice that the deterrence effect of the same form of punishment may vary among types of offenders. For instance, if an offender is considered by professionals to be at a high risk of reoffending, then imprisonment has high deterrence value because it separates him from the community and incapacitates him. In other words, sending a high-risk offender to prison is highly likely to deter crime. On the other hand, imprisonment may have little deterrence value when imposed on offenders who are not likely to commit crimes again-for example, a thief who steals food because her children are starving is not likely to commit the same offense again when social welfare supports or a career opportunity become available. A police officer who takes bribes is not likely to commit the same crime again if he is permanently deprived of his privilege to serve as an officer. In these cases, community-based sanctions may be preferable to incarceration because these offenders are not likely to reoffend and alternative forms of punishment that cause less harm to the offender and the society are available. In addition, even in cases in which imprisonment is necessary, we must also take into consideration the prisonization effect of correctional facilities-the more one has acclimated oneself to the prison culture, the more difficult it becomes to adapt to life back in the community. In short, in determining how to punish an offender, a deterrence theorist does not consider whether the sentence suits the moral desert of the offender. ${ }^{4}$ Instead, she considers whether a form of punishment will likely increase or decrease the offender's chance of reoffending and the way the punishment is likely to affect the community in the future. ${ }^{5}$

\section{ii. Compatibility with Different Conceptions of Crime}

It is important to note that, even though the deterrence theory tells us how punishment can deter crime, by itself the theory does not tell us what a crime is and why we must deter it. For the purposes of this article, I will assume that a crime is a public wrong, and that when a person commits a crime the state has the authority to intervene. When an act is criminalized, anyone who performs this act will be punished, even when all parties involved are consenting adults. To know what a crime is, we need to know the scope of the government's authority. Does the government have the authority to enforce all true moral laws, or does it have authority over other-regarding affairs only? Is the government morally justified in criminalizing actions that do not cause harm, but will offend the moral sentiment of the community? In general, a deterrence theory does not answer these questions, but can be compatible with different answers to themlegal moralism, ${ }^{6}$ the offense 
principle, ${ }^{7}$ the harm principle, ${ }^{8}$ etc. In other words, this definition of a deterrence theory can be compatible with different principles of political authority.

We can distinguish between two types of principle regarding political authority - a fully moralized, and a partially moralized or non-moralized one. A principle of political authority is fully moralized when it is based on some comprehensive moral doctrine. Fully moralized theories of political authority hold that governments have the authority to enforce all moral laws in society. Accordingly, governments also have the authority to criminalize immoral behavior and punish offenders. On the other hand, according to non-moralized (or partially moralized) principles of political authority, a government does not have the authority to enforce moral law, and thus it does not have the authority to criminalize behaviors that are considered immoral. This, however, does not mean that the government does not have the authority to criminalize certain behaviors. For non-moralized theories, the justification for criminalizing particular behaviors may appeal to considerations that are not based on any comprehensive moral doctrine-for example, individual rights, public safety, national security, communal integrity, etc. These considerations are not based on any comprehensive moral doctrine and thus are based only partially (if at all) on morality.

Notice that both moralized and non-moralized theories of political authority can be compatible with the instrumental value view of criminal punishment. One may suspect that a philosopher who subscribes to some moralized principle of political authority must also hold an intrinsic value view of punishment, because she believes that government has the moral authority to implement moral laws. Nevertheless, a moralized theory can also be compatible with the instrumental value view of punishment. For instance, one may believe that punishment can serve as a tool to reinforce individual morality such as personal virtue or character. In the past, adultery, prostitution, and sodomy were criminalized and punishable by severe sentences. The rationale behind such criminal legislation is based on the assumption that governments have the authority to implement moral laws by punishing those who violate them, and that punishment is justified because offenders deserve the ill-treatment. However, the same punishment can also be justified by the instrumental value of punishment if it is assumed that the government wishes to deter actual and potential offenses. Punishment, then, is used to reinforce moral principles, presumably by "scaring offenders straight." ${ }^{\prime 9}$

Punishment can also be used to reinforce some communal norm that is not based on any comprehensive moral doctrine-for example, social harmony, a social contract, or norms about individual rights or homeland security. As Thomas Hobbes suggests, "Covenants, without the Sword, are but Words, and of no strength to secure a man at all." ${ }^{10}$ Punishment is justified because it helps to reinforce a social norm. However, this says nothing about the content of the social norm. The norm can be capitalist, socialist, liberal, or tyrannical. A tyrant can use punishment to consolidate his rule, and a liberal democracy can use punishment to protect individual autonomy, rights, and freedom. Punishment is a means, an 
instrument. Different societies can use it to reinforce different social norms.

In short, deterrence theory as a view about the function of punishment can be compatible with different principles of political authority. It is a morally neutral theory that can be compatible with a variety of comprehensive and non-comprehensive moral doctrines. Whether punishment should deter actual offenders (incapacitation) or potential offenders (general deterrence) depends on the theory of political morality that one subscribes to-some might think that the end of punishment is to reinforce some social norm, others to protect personal virtue. They might also prescribe different methods of punishment to achieve their ends.

\section{iii. Means, Ends, and the Minimum Rationality Requirement}

So far, I have explained that a deterrence theory must adopt the instrumental value of punishment, and that it is for that reason compatible with different conceptions of crime and different theories of political morality. Thus, there is no single conception of crime that all deterrence theorists must adopt, nor a principle of political authority that they must accept. Different deterrence theorists have different views on these matters.

Nevertheless, it is important to note that all deterrence theories must be limited by a minimal rationality requirement-given that punishment is regarded as a means to achieving some important objective, the use of a means must be justified as well as constrained by the end it serves. This rationality requirement is minimal because it only requires that, whatever end we pursue, we do not pursue it in a way that impedes pursuit of this end. It does not tell us what our ends are. Rather, it asks that we select the means that would likely contribute to our end, and that we do not select the ones that would likely impede its pursuit. It does not prescribe in a substantive way the desirable forms of punishment, but only asks that a deterrence theorist impose punishment with an eye to punishment's impact on the overriding objective of the criminal justice system. Because different deterrence theorists have different views of the objective of the criminal justice system, the minimal rationality requirement imposes different constraints on them. Notice that certain short-term harms to an important value may be permissible when relevant measures will lead to realization of more important values in the long term.

In the context of criminal punishment, this means that, whatever we do to deter crime, we must not adopt a form of punishment that would cause harm to the overriding aim of the criminal justice system. In practice, the minimal rationality requirement demands that we examine the likely consequences of a form of punishment before imposing it on an offender. This is an important requirement ignored by many deterrence theorists. For instance, mixedtheorists may argue that punishment can be justified on deterrence grounds and go on to prescribe proportionate sentencing without considering its impact. ${ }^{11}$ According to them, proportionate sentencing, which requires that states impose proportionate harm on offenders, will deter crime and thus proportionate sentencing is justified for non-retributive, deterrence reasons. 
There are several problems with this line of reasoning, and an important one is that it ignores that, in actual practice, proportionate sentencing may violate the minimal rationality requirement. For instance, proportionate sentencing may force an offender to acclimate herself to the prison culture, thereby undermining her capacity to live a decent, normal life in the community. This effect of imprisonment might make criminal activities more desirable for her and may for this reason be detrimental to the community because, instead of helping to reform and rehabilitate an offender, society helped to create a repeat offender.

Because philosophers have different views on the correct principle of political morality and the government's authority to punish, the minimum rationality requirement imposes different demands on them. Here, I cannot provide a full defense of my preferred principle of political morality. I shall simply follow the principle prescribed by John Stuart Mill in On Liberty. In a liberal democratic society, the constitution protects the basic rights and liberties of individual citizens. In this way, the government's political authority is limited and the freedoms of individuals secured. Still, in such a society, the government has the authority to impose criminal law as a way of protecting the basic rights and freedoms of citizens. Following Mill, I shall assume that a liberal government has the authority to punish those whose actions cause other-regarding harm. Actual criminal laws can be more or less liberal. The political morality in such a society dictates that individuals have rights, and the end of criminal punishment is to protect basic rights. If the aim of punishment is to protect basic rights and freedom of citizens, then in determining which forms of punishment should be imposed on an offender, we must consider whether or not a particular form of punishment will help to protect citizens' rights and consolidate the norms of a liberal society. Cesare Beccaria similarly argues that punishment is justified and constrained by "the necessity of defending the public liberty" - the idea is that if the imposition of punishment does not protect public liberty, then punishment is not morally justified. ${ }^{12}$

\section{Punitive External Sanction - The Traditional Conception of Deterrence}

So far, I have described two assumptions of a deterrence theory and analyzed their implications. Next, let us consider the traditional conception of deterrence. The second assumption of standard deterrence theory holds that punishment is intended to dissuade potential offenders from committing crimes. This seems to imply that, if we can increase the loss and burden associated with criminal conduct by imposing a more severe punishment, then we can proportionately weaken a potential offender's incentive to commit a crime. Common sense dictates that the worse a form of treatment is, the stronger the fear it instills in rational 
agents, and the less likely the agents will engage in the activity that will bring about the ill-treatment. This is the root of traditional deterrence theories: rational agents fear ill-treatment; thus, we can intimidate them to obey the law by attaching ill-treatment to criminal offense.

For this reason, criminal punishment is typically associated with some negative experience-a fine deprives a person of her property; community service imposes an unchosen burden on the offender; imprisonment deprives an offender of her rights to many freedoms, including the right to individual autonomy; disenfranchisement deprives the offender of her civil right to vote; and the death penalty deprives an offender of her life. The idea of crime deterrence is to make criminal offenses unrewarding or even counterproductive. ${ }^{13}$ In this way, criminal activities become irrational, and rational agents will act more cautiously to avoid committing a crime. This is why, traditionally, the concept of deterrence is characteristically associated with the idea of punitive, external sanction.
How severe should punishment be, then, to deter offenders? Deterrence theorists have different views on this matter-some argue that punishment must be proportionate to the crime $;{ }^{14}$ others argue that the more severe the punishment, the better; ${ }^{15}$ and still others believe that we may use only the minimum punishment necessary. ${ }^{16}$ Given the length constraints of this article, I cannot consider in detail the debate among deterrence theorists regarding the desirability of severe punishment. I shall only note that not all deterrence theorists are in favor of severe punishment. For instance, Cesare Beccaria argues that the deterrent effect of a form of punishment is determined not solely by its severity, but also by other factors. For example, an offender might receive a sentence of lifelong torture. Such a severe penalty might at the beginning impose a shocking image on the mind and effectively deter observers from criminal offenses. However, people are forgetful. As time passes, we are likely to become numbed, so that knowledge of such a severe penalty no longer leaves a striking image on our minds. ${ }^{17}$

\section{The Limits of Traditional Deterrence Theories}

Now that we understand what motivates the traditional conception of deterrence, let us consider the limitations of the traditional theory. Once we perceive the limitations of standard deterrence theory, we can go on to consider whether we should abandon the theory, or if it is possible to revise it and develop a more plausible deterrence theory.

\section{i. Cases in Which Traditional} Deterrence Tools Are Ineffectual In section I, I argued that a deterrence theory makes two assumptions:

(1) Potential criminal offenders are rational agents capable of taking into consideration the likely consequences of their actions.

(2) Punishment gives a potential offender a reason not to commit the crime. 
In other words, in any given case, for punishment to effectively deter crime, both conditions must apply. If any of the assumptions does not apply to a particular case, punishment will not produce the desired deterrent effect.

Therefore, we can immediately infer the following conclusions:

(A) Criminal punishment effectively deters those who meet both conditions (1) and (2).

(B) Criminal punishment cannot deter those who do not meet both conditions.

While conclusion (A) specifies the domain of cases in which punishment will deter crime, conclusion (B) describes cases in which punishment cannot deter crime. In civilized societies, most people belong to category (A). This fact, however, is not very reassuring as it leaves ample room for crimes that cannot be deterred by punishment-namely, those committed by people who do not meet both conditions. This is the limit of traditional deterrence theories-namely, that punishment cannot effectively deter all types of criminal.

The next question is whether we should abandon the deterrence theory, or whether it is possible to develop alternative forms of punishment that can more effectively deter crime. Let us consider cases that fall into category (B) and see if there is anything we can do to deter actual and potential offenders in this category. Cases in which criminal punishment cannot deter crime fall into three categories:

(B1)People who are not fully rational (who fail to meet assumption [1])
For punishment to deter crime, a potential offender must have the mental capacity to grasp the consequences of her actions. If a potential offender is not sufficiently rational, then she cannot take into account the consequences of her action. Punishment cannot deter a person who is not sufficiently rational.

There are at least two types of offenders who fall into this category. First, some people suffer from persistent or long-term cognitive deficiencies that prevent them from developing fully the mental capacity required for rational thinking-for example, low intelligence, mental and/or psychological illness, and personality disorder (B1-1). Second, some rational agents may possess the capacities necessary for rational decisionmaking, but may lose this capacity temporarily on occasion-for example, after intoxication, drug use, sleep deprivation, or sudden overflow of strong emotions (anger, depression, anxiety, fear) (B1-2). In the second type of case, although agents have acquired fully the capacity to think rationally, their judgments may temporarily be clouded by spates of strong emotions. When this happens, their capacity for rational thinking may be disabled briefly, and they may instead follow the command of their emotions and not their reason. After calming down, they may regain their capacity to think rationally. When this happens, they may or may not regret what they did. However, when people are overwhelmed by strong emotions, they may not be able to make rational decisions. The prospect of punishment cannot deter them from engaging in criminal conduct.

Is it possible to deter people who are not fully rational? Let us consider 
these two types of cases. First, we should note that in many societies, patients who suffer from mental illness or personality disorder are sometimes exempt from criminal responsibility. Depending on the nature of the illness, the symptoms, and the insight of the patient, some patients can be held responsible for (some of) their actions, while others cannot. I should also note that people with mental illness pose a challenge to criminal punishment in general, not just to deterrence theories. This does not mean that they hold a trump card for criminal offenses. Courts may require patients to undergo therapy and treatment, be hospitalized, and be separated from the community when necessary. While these measures are mandatory, they are not punitive but necessary safety measures.

As to the second type of offender, many criminologists suggest that crimes are committed in the heat of passion, when one is not thinking rationally. Thus, it is impossible to deter this type of offender because we cannot be sure that people will always stay calm and level-headed. While there is some truth in this suggestion, it is not true that there is nothing we can do to deter this type of offender. Those who are not in perfect control of their emotions and impulses might come to acquire the skills and techniques necessary when properly trained. For instance, sometimes a court may order mandatory anger management lessons or other psychotherapy to help offenders learn to control their emotions and impulses. If successful, these lessons and treatments will help an offender to control her behavior and greatly reduce the recidivism rate. These treatments and courses are not punitive external sanctions, but require that participants make internal changes. From the perspective of crime deterrence, these programs have positive deterrence value when applied to offenders in need. Such measures are commonly accepted in many societies as a valid form of punishment.

(B2) People who do not fear punishment (who fail to meet assumption [2])

Among rational agents, some fear punishment, others do not. When rational agents do not fear punishment, they also pose a challenge to crime deterrence. There are several types of people who will not be deterred by the prospect of punishment, including people who have false beliefs, people who have distorted values, and people who have nothing to lose.

First, depending on the content, a person who has false beliefs may not be deterred by the prospect of punishment. For instance, a person who believes that he will go to heaven after he murders an innocent person will not be deterred even by the death penalty. A person who believes that "no" means "yes" will not be deterred by 10 years of incarceration because he believes that his victim was actually saying "yes." This type of offender can be deterred only when they correct their beliefs and learn certain facts. This requires that mandatory education programs be imposed on them; otherwise there is no guarantee that they will avoid engaging in similar criminal behavior in the future. This is done by correctional facilities in many societies; for instance, sex offenders are ordered to take gender equality courses. The assumption behind such mandatory 
courses is that once offenders acquire the right kind of beliefs and understanding of facts, they will learn to respect the bodily autonomy of persons. Without learning this information, we have no assurance that they will not commit the same crime again.

Second, there are people who consider punishment a price worth paying. Among them, some have sound moral justification for their beliefs (e.g., civil rights activists and conscientious objectors), others simply have distorted beliefs about values. For instance, some people might consider imprisonment a way of accessing social welfare. Prisons offer free food, shelter, and possibly health care. For a person who lacks the motivation to work, being in prison might be a good way to improve the quality of her life effortlessly. Moreover, some people might consider criminal punishment a price worth paying: they may feel that, although criminal activities-selling illegal substances, using weapons, human trafficking, etc. - are risky, the reward is lucrative, and the risk worth taking. Imprisonment may also be considered a mark of honor among gang members, a sign that one is deemed dangerous and a threat to society. In addition, an offender may be ready to accept the consequences of her actions. For instance, it is not uncommon for murderers to commit suicide after killing their victims. To deter this type of offender, society must help them to examine their values and convince them that they are wrong. Unless their beliefs about value change, and criminal activity continues to pay, why would they not commit the same crimes again?

Third, there are people who feel that they have nothing to lose by committing a crime-for example, people who are in conditions of extreme poverty, or people who are about to die. Among the first group of people, some may feel that to stay alive they have to resort to criminal activity for a living-stealing food, water, or life-sustaining medicine. Depending on their own financial conditions and the resources available in society, they may or may not be justified in resorting to crime. There is some controversy as to whether this type of offender should be punished. In some societies, stealing is a criminal offense, regardless of the circumstances of the thief. In other societies, stealing out of necessity is not a crime, given that stealing may be morally justified by the offender's human right to life. ${ }^{18}$ In any case, to deter this type of crime, governments must make sure that access to basic social welfare and equality of opportunity are secured. Otherwise, when a person sees no hope in securing a suitable career, she may have to resort to criminal activities to keep herself alive. ${ }^{19}$ To deter this type of criminal activity, we need to have adequate social welfare policies. Unless citizens have secure access to basic goods to sustain their lives, povertyrelated crime will not stop.

The second group of offenders who have nothing to lose are people who suffer from terminal illness and those who are sentenced to life imprisonment or the death penalty. A person suffering from terminal illness may feel that she may not live long enough to stand trial, not to mention being imprisoned or receiving the death penalty. Punishment in any form cannot deter her. The same goes with an offender who is sentenced to life imprisonment or the death penalty. What else can the 
state do to make her life worse? Since things can't get worse, one might as well just live it up.

It is important to note this side effect of severe punishmentnamely, the nothing-to-lose mentality. A rational agent who receives the death penalty may feel that she has no reason to prioritize the community over her own self-preservation. She is a person who returns to the Hobbesian state of nature-the commands of law no longer apply to her as her self-preservation trumps the demand of civil laws. ${ }^{20}$ From her perspective, there is not much to lose. For selfpreservation, she might be willing to kill innocent persons or cause harm to the community because she has lost her place in society and there is nothing worse that society can do to her. In short, severe punishment also carries substantive negative deterrence value, an important factor that any serious deterrence theorist must bear in mind.

Most inmates who receive long sentences including life sentences and the death penalty are classified by prisons as dangerous and sent to maximum-security facilities. One explanation is that this gives them what they deserve, but it is not clear why longer sentences do not already account for the desert of severe punishment. A more plausible explanation is that they are at higher risks of escaping because they have less to lose and more to gain if they successfully escape from prison. In other words, for someone who would receive a weighty sentence, violating the law again may appear to be preferable to the prospect of enduring ta sentence felt to be unbearable.

Is it possible to deter those who have nothing to lose? It is difficult but not impossible. When a person has a sense of self-respect and honor, she may feel that she is not the type of person who does certain things. In this case, she may not do those things even when no punishment will follow. This disposition requires education and possibly also a strong belief in one's self-worth, which many actual offenders do not have (for example because their parents or teachers told them that they are hopeless).

(B3) People who consider themselves above the law (who meet both assumptions)

Even when a potential offender is rational and fears punishment, she will not be deterred if she is confident that the punishment will not follow her offense. This may happen under at least two circumstances. First, when an offender is confident that the evidence available is not sufficient for prosecution, she will not be deterred by the prospect of punishment. This happens when there is insufficient evidence or when the offender is in a position to dispose of the evidence. In these cases, the person may be confident that she will not be prosecuted. For instance, prosecutors, detectives, forensic experts, etc. have at least partial control of the criminal justice procedure and may feel confident that they will not be caught. Second, a rational offender may have already made arrangements to avoid prosecution-bribing relevant law enforcement personnel or moving beyond the current jurisdiction for example.

Even the severest punishment cannot deter this type of offender. Many criminologists and philosophers have noted that the most important consideration in an offender's deliberation is not the severity of 
punishment, but its certainty. ${ }^{21}$ If there is hope of escape, then even the worst punishment may not deter.

Is there any other way to deter this type of offender? There are two strategies we can adopt to strengthen the deterrence value of punishment. The first requires that we improve upon the criminal justice system. Criminal justice is a form of imperfect procedural justice and it is always possible that a guilty person will be freed and an innocent person convicted. This problem poses a challenge to the institution of criminal punishment in general, not just to deterrence theories. Non-deterrence theorists also have to worry about the accuracy and effectiveness of procedural justice. Unless we believe that proof and evidence are not important, if we think it is crucial to prove a person's guilt before punishing him, we need to face this problem.

The second strategy to deter this type of potential offender is again to make sure that citizens and officials have right beliefs about facts and values. Otherwise, a person is likely to abuse her authority and privileges when doing so will serve her personal interests. Unless a person respects the rights and interests of others, they will not feel bad about taking advantage of others when no one will notice.

\section{ii. Where Do Traditional Theories Go Wrong?}

We can see the limitations of traditional deterrence theories more clearly now. Regardless of the severity of punishment a theory recommends, traditional theories are shallow in that punishment deters only those who respond to external, punitive sanctions. When somebody is sure that she will not be caught, she will not be deterred. Further, without trying to convince her otherwise, an offender is likely to have the same beliefs about facts and values that led her to criminal offenses in the first place. Such a person is likely to reoffend even after being punished. This type of deterrence punishment does not address the root cause of crime and is therefore shallow. ${ }^{22}$

In addition, according to traditional deterrence theories, the aim of punishment is to deter potential offenders. This is the basis on which they prescribe punitive forms of punishment-severe or proportionate. However, this oversimplified reasoning ignores the minimal rationality requirement, which suggests that no matter how we punish an offender, we should not do so in a way that harms our long-term aim. In the case of traditional theories, both severe and proportionate punishment may possibly violate the minimal rationality requirement, as both simply do not consider the consequences and side effects of a form of punishment. A deterrence theorist who prescribes that punishment be proportionate or severe completely ignores the longterm impact of punishment and does not take into consideration whether punishment will lead to more crime. It is not unfair to say that these deterrence theorists do not take crime fighting seriously.

Before moving on, I should note that in cases in which punishment does not seem to deter crimenamely, cases (B1) to (B3), external sanction provides a limited deterrent effect. Does this mean that deterrence theories are useless? No. I have suggested several alternative strategies that we can adopt to fight crime more effectively-imposition 
of treatment (B1-2) and education programs (B2-1, B2-2), provision of key social resources including basic social welfare and equal opportunity (B2-3), strengthening crime-solving skills and technology (B3-1), and inculcating a sense of honor and selfrespect among citizens (B3-1, B3-2). These strategies require that governments make policy changes not only in the criminal justice system, but also in other public institutions such as welfare and education. I have also suggested that in many cases the government must try to change the mind of the offenders - to help them learn to control their emotions and impulses, to educate them about correct beliefs and values, and to learn to respect themselves and other human beings. To achieve these goals, we must impose on offenders mandatory education programs and even psychotherapies when necessary. Mere external sanctions cannot fulfill these purposes; internal sanctions are also indispensable.

Some readers might wonder whether mandatory education programs and treatments are punishment or rather benefits, as they are not punitive and hardly painful, and thus may not constitute proper punishment. I cannot respond to this challenge fully in this article. Very briefly, the deprivation of civic liberty is by itself considered to be a form of punishment among professionals today. ${ }^{23}$ When a child is grounded, or when an activist is placed under house arrest, they are deprived of their rights to liberty. These forms of treatment are neither punitive nor painful; nonetheless, they clearly are examples of punishment. Likewise, deprivation of rights to civic liberty in any form-disenfranchisement, imprisonment, mandatory education or treatment-are also forms of punishment.

\section{The Deep Deterrence Theory}

So far, I have described the structure of deterrence theories of punishment and explained the scope and limitations of traditional deterrence theories. Traditional theories deem punishment as a form of punitive external sanction. This results in a lack of flexibility in its prescription of punishment-we can only increase or decrease the severity of external punitive sanction; other than that, there is not much we can do. The traditional theory offers limited and shallow deterrent effects.

While severe sanctions might deter quite effectively, the deterrent effect is not unlimited, and punitive forms of punishment may also carry significant negative deterrence value.
When this happens it will be helpful if we can also appeal to internal sanctions to increase the deterrent effect. We should not limit ourselves to the traditional deterrent tools only; what we need is more flexibility in our choice of sanctions. A rational deterrence theorist should not abandon any form of sanctions easily; she should keep in her hands as many tools as possible, including both internal and external sanctions.

In section I, I suggested that the function of punishment is to deter crime, or to dissuade potential offenders from committing criminal offenses. Given that potential offenders have different values and beliefs, the easiest way to give all of 
them a reason against committing crimes is by imposing some kind of punitive treatment on actual offenders. People fear different things, and it is not feasible for the law to prescribe separate treatment for different individuals. Punitive forms of punishment are the common denominator that most people fear. Thus, we use punitive sanctions to deter crime. However, the easiest way is neither the only way nor the best way. We have seen in section IV that there are considerable limitations to punitive external sanctions. Not only do severe external sanctions provide limited deterrence value, they sometimes carry negative deterrence value. Traditional deterrence theories are said to have limited deterrent force because they appeal only to fear of external sanction. Thus, if an offender is confident that she will not be caught, or if she is willing to accept the punishment, then punishment cannot prevent her from committing a crime. Confucius' criticism of legalism provides a good starting point from which we may revise and improve upon the shallow deterrence theory. Commenting on the legalist philosophy of severe punishment, Confucius suggests that

[i]f you try to guide the common people with coercive regulations and keep them in line with punishments, the common people will become evasive and will have no sense of shame. If, however, you guide them with Virtue, and keep them in line by means of ritual, the people will have a sense of shame and will rectify themselves. ${ }^{24}$

Confucius points out an important defect of traditional deterrence theories-namely, that they guide offenders only with external sanctions and thus have limited deterrent effect. While one may agree with
Confucius' prognosis, one may disagree with Confucius' prescriptionnamely, to guide citizens with virtue. Modern liberals may be concerned that Confucius' solution is based on virtue ethics and therefore incompatible with liberal respect of individual autonomy and state neutrality. Nevertheless, Confucius makes an important point about crime deterrencenamely, that effective deterrence comes not from outside but from within. ${ }^{25}$ One need not agree with his prescription; rather, the point is to note that only through internal change will offenders ethically reform themselves. This position is in congruence with Beccaria's acknowledgment that "the most certain method of preventing crimes is to perfect the system of education." ${ }^{26}$ Human beings are capable of entertaining a variety of reasons, including both prudential and moral reasons. They both help to deter crime. However, non-prudential moral reasons are deep deterrents because a believer in moral principles will avoid committing criminal offenses even when no punishment will ensue. For this reason, deep deterrents are preferable to shallow deterrents.

Let me briefly recount a true story to illustrate how deep deterrence works. Mr. Lin used to work for a loan shark, and his duty was to harass those debtors who failed to pay their debts on time. If a debtor did not pay the loan shark back, Mr. Lin resorted to violence or public humiliation (distributing flyers in the debtor's neighborhood, pouring paint on their cars, or writing on their houses or cars to humiliate the debtors) to pressure debtors to pay back what they owed. When they were not able to do so, his company 
would offer them jobs in the sex industry or the drug trade. In this way, debtors could more efficiently pay off their debts. He never felt bad about what he did.

One day, he was driving on the highway. He witnessed a school bus catch on fire right in front of his vehicle. He immediately ran to rescue the kindergartners, without thinking that he too might catch on fire. In the end, he was not able to save everyone, but he did save many children. He was described as a hero by the reporters and media covering this incident.

During a TV interview, Mr. Lin said that after this incident he really started to think about his life and realized that what he previously did was meaningless. He soon quit his job and opened a small restaurant selling stinky tofu. ${ }^{27}$

It is not clear what Mr. Lin meant when he said that his old occupation was meaningless. However, it seems quite clear to me that it is Mr. Lin's newly acquired identity as a hero that drove him away from his previous deviance. Prior to the school bus incident, he had little regard for the well-being of others and did not feel bad about ruining other people's lives. However, his new sense of himself as a hero is incompatible with his previous criminal lifestyle. No reporter talked about his previous criminal career; those who regarded him as a hero did not know or care about what he did before. However, he came to the realization that his earlier lifestyle was "meaningless," without other people judging it to be so. It seems to me that his transformation was the result of his newly gained identity as a respectable hero. Heroes do not ruin other people's lives. Once he had this insight, it became very important to him not to continue his criminal career.

\section{The Wide-Scope Deterrence Theory}

I have described the limitations of traditional, shallow deterrence theories. I have also explained how we can fight crime more effectively by including deep deterrents. Although deep deterrents are more effective in crime fighting, we should not rely solely on them, as we cannot be sure that all offenders will receive education or treatment programs well. Thus, a prudent deterrence theorist must embrace both shallow and deep deterrence tools. This is why I call the new theory the wide-scope theory. The wide-scope theory holds that both shallow and deep deterrents-prudential reasons and moral reasons-are powerful tools in deterring crime. Thus, a society must retain both in the criminal justice system. We should not focus narrowly on punitive external sanctions, but must also make use of internal sanctions, especially because the latter carry deeper deterrent effects. Notice that, while a widescope theorist may value deep deterrents more than shallow deterrents, she is not against using the latter when it is necessary. That is, even though a severe penalty may carry severe risk, a wide-scope deterrence theory does not exclude its use in principle. Thus, although a wide-scope deterrence theorist may see the death penalty or severe, punitive sentences as risky, she may endorse this type of sanction if it is necessary to secure the long-term objective of the 
institution (e.g., the protection of basic rights). ${ }^{28}$

One way to understand the widescope theory is by looking at the different levels of aims it tries to achieve. In punishment, there are different levels of success. The lowest level is achieved when an offender learns about the law and tries to avoid committing a crime because she fears punishment. The highest level is achieved when the offender learns to respect the rights of others and acts accordingly, without considering the punishment attached to a violation.

\section{Objection}

Given that the deep theory requires that we offer offenders moral reasons against committing criminal offenses, some readers might suspect that the theory is paternalistic and incompatible with liberalism's commitment to state neutrality. Liberalism requires that governmental institutions remain neutral with respect to different comprehensive moral doctrines. If correctional staff and wardens are allowed or even required to provide moral reasons to prison inmates, would the resulting policy violate the requirement of state neutrality? If state governments give moral reasons against criminal offenses, isn't such a policy paternalistic and disrespectful of the autonomy of offenders?

Whether a state violates the autonomy constraint depends on two factors: the content of the moral reasons offered and the method of teaching those moral reasons. First, whether we are imposing a moral view on offenders depends on what we teach them. If we teach them one particular comprehensive moral doctrine and tell them that anything that contradicts this doctrine is false, then our teaching is paternalistic and violates the principle of state neutrality. On the other hand, if we just teach them moral theory-Aristotelian ethics, Bentham's utilitarianism, Kant's categorical imperative, egoism, the harm principle, or even legal moralism - the approach is not paternalistic. Professors teach ethics all the time. We teach students that what important philosophers say is the right thing to do. We teach students how to apply these principles to make their decisions. We teach them how to evaluate moral arguments and ask them to decide for themselves whether they like the arguments. Students decide for themselves whether they agree or disagree with the ethical theories. When one teaches ethics, what one does is offer information about ethical theories or views, not indoctrination. Giving information, even about comprehensive moral doctrines, is not necessarily paternalistic.

Further, the most important aspect in the education of offenders is to teach them to respect the rights of other citizens. To convey this knowledge, we can provide moral or legal education. We can teach offenders why, morally speaking, they must respect the rights of their fellow citizens. After learning the moral reasons why one must respect the rights of others, offenders may or may not take the rights of others seriously. We may teach them about the law by telling them what types of behaviors are prohibited by the law and what form of punishment will ensue if one breaks the law. 
Such legal education does not involve imposing any particular moral view on offenders. Unless having a criminal law already violates the principle of state neutrality, teaching inmates about the same code does not violate the neutrality principle.

Moreover, whether correction policies are paternalistic depends on what we do to motivate offenders. There are ways to provide moral reasons that are paternalistic and there are ways that are not. Incentives to sign up for these programs can be given. For instance, the prison can give credit to those who sign up for these programs and allow participation to count in favor of early parole. Correctional facilities may also help match interested inmates with volunteer teachers from various religious or non-religious backgrounds to help inmates learn lessons about how to lead a good life. In any case, achieving the goal of deep deterrence does not require paternalistic measures that violate the principle of liberal neutrality.

\section{Conclusion}

In this article, I have described the structure of deterrence theories of punishment. I have also examined the traditional conception of deterrence and shown that it fails to take crime deterrence seriously. After analyzing the limitations of the traditional theory, I argue that we can expand the tools of deterrence by including both internal and external sanctions in the criminal justice system. External sanctions such as punitive forms of punishment offer shallow deterrence, but internal sanctions carry deep deterrent effects. My theory greatly expands the scope of useful deterrents in the criminal justice system and allows more flexibility in the fight against crime.

\section{Notes}

[Disclosure statement: No potential conflict of interest was reported by the author.]

[This work was supported by the City University of Hong Kong [grant number 7200410].]

1 In this article, I will assume without argument that punishment involves deprivation of rights to certain liberties as a response to some norm-violating behavior. It need not involve pain, suffering, hard treatment, or stigmatization.

2 In cases like this, an offender who causes damage to the interests of others may still have the duty to compensate the victim for her loss; however, we cannot blame her for her action as she cannot be held responsible for the consequence of her action.
3 For an account of desert-based retributivism, see Moore, Placing Blame; Kershnar, "Justification of Deserved Punishment"; and Kershnar, "Basis of Deserved Punishment." For fairness-based retributivism, see Rawls, "Legal Obligation"; Dagger, "Playing Fair with Punishment"; and Von Hirsch, Censure and Sanctions.

4 Here, I assume that punishment and compensation are separate: the former is an offender-centered concept while the latter is victim-centered. Typically, when an offender is punished-for example, 
imprisoned or sentenced to community service-this does not affect the well-being of the victim. Strictly speaking, punishment does not affect a victim's welfare, while compensation does. In other words, victims have the right to demand that their losses be compensated, but they do not have the right to demand that an offender be punished in a particular way.

5 The principle described here is commonly accepted by modern penal institutions. For instance, the Principle of Normality in Norwegian Corrections states: “(1) The punishment is the restriction of liberty; no other rights have been removed by the sentencing court. Therefore the sentenced offender has all the same rights as all other [sic] who live in Norway. (2) No-one shall serve their sentence under stricter circumstances than necessary for the security in the community. Therefore offenders shall be placed in the lowest possible security regime. (3) During the serving of a sentence, life inside will resemble life outside as much as possible." Kriminalomsorgen, "About the Norwegian Correctional Service." http://www. kriminalomsorgen.no/index.php?cat=265199

6 See Devlin, Enforcement of Morals, 6-10.

7 See Feinberg, Offense to Others.

8 See Mill, On Liberty, 14.

9 See Cullen and Johnson, Correctional Theory-Context and Consequences; Nagin, "Criminal Deterrence Research at the Outset of the Twenty-First Century."; Nagin, "Deterrence: A Review of the Evidence by a Criminologist for Economists."

10 Hobbes, Leviathan, 223.

11 See Hart, Punishment and Responsibility. I suspect that many self-labeled deterrence theorists belong to this campAnthony Ellis, Daniel Farrell, Philip Montague, Victor Tadros, and Warren Quinn. See Ellis, "Deterence Theory"; Farrell, "Justification of General Deterrence"; Montague, Punishment as Societal-Defense; Tadros, Ends of Harm; Quinn, "Right to Threaten." 3-4.

12 Beccaria, On Crimes and Punishments,

13 See Bentham, Principles of Morals, 184.

14 Most self-labeled deterrence theorists today belong to this camp. See Ellis,
"Deterrence Theory"; Farrell, “On Threats and Punishments"; Quinn, "Right to Threaten"; and Tadros, Ends of Harm.

15 See Guanzi, Book of Lord Shang, 197.

16 See Beccaria, On Crimes and Punishments, 3, 27; Deigh, "Punishment and Proportionality"; Hobbes, Leviathan, 389.

17 See Beccaria, On Crimes and Punishments, 63-4.

\section{Moisescu, "Stealing Food."}

19 Several philosophers argue that whether an individual has a duty to comply with the demands of public institutions depends on the morality the institution. See Murphy, "Marxism and Retribution"; Scanlon, "Individual Morality"; and Shelby, "Dark Ghetto."

20 As Hobbes argues, "[ $\mathrm{t}]$ he Obligation of Subjects to the Sovereign, is understood to last as long, and no longer, than the power lasteth, by which he is able to protect them. For the right men have by Nature to protect themselves, when none else can protect them, can by no Covenant be relinquished.... The end of Obedience is Protection." Leviathan, 22.

21 See, e.g., Beccaria, On Crimes and Punishments, 63.

22 Anthony Duff presents a similar critique. See Duff, Trials and Punishment, 268-9.

23 This is acknowledged by many state governments. For instance, see the first point of the Principle of Normality in the Norwegian correctional service statement mentioned in note 5 . It can also be found in Coyle, Human Rights Approach.

24 道之以政，齊之以刑，民免而無恥; 道之 以德, 齊之以禮, 有恥且格。See Confucius, Analects, 5.

25 A detailed discussion of the Confucian conception of shame can be found in Justin Tiwald's article "Punishment and Autonomous Shame in Confucian Thought" in this issue. 107.

26 Beccaria, On Crimes and Punishments,

27 See Peng, "Putting Down the Butcher's Knife."

28 For instance, whether an offender is considered rehabilitable is very important 
in murder cases in Taiwan. Many judges justify the decision to impose a life sentence by citing evidence that the offender is "rehabilitable." On the other hand, decisions to impose the death penalty typically cite evidence that shows that it is almost impossible to rehabilitate the offender.

\section{Bibliography}

Beccaria, Cesare. On Crimes and Punishments. Edited by Aaron Thomas. Translated by Aaron Thomas and Jeremy Parzen. Toronto: University of Toronto Press, 2006.

Bentham, Jeremy. An Introduction to the Principles of Morals and Legislation. New York: Dover Publications, 2007.

Confucius. The Analects. In Readings in Classical Chinese Philosophy, 2nd ed., edited by Philip J. Ivanhoe and Bryan W. Van Norden, 1-57. Indianapolis: Hackett, 2005.

Coyle, Andrew. A Human Rights Approach to Prison Management: Handbook for Prison Staff. 2nd ed. London: International Centre for Prison Studies, 2009.

Cullen, Francis T., and Jonson, Cheryl Lero. "Deterrence: Scaring Offenders Straight." Chap. 4 in Correctional Theory-Context and Consequences. Thousand Oaks, CA: Sage, 2012.

Dagger, Richard. "Playing Fair with Punishment." Ethics 103, no. 3 (1993): 473-88.

Deigh, John. "Punishment and Proportionality." Criminal Justice Ethics 33, no. 3 (2014): 185-99.

Devlin, Patrick. The Enforcement of Morals. Oxford: Oxford University Press, 1965.

Duff, R. Anthony. Trials and Punishments. Cambridge: Cambridge University Press, 1986.

Ellis, Anthony. "A Deterrence Theory of Punishment." Philosophical Quarterly 53, no. 212 (2003): 337-51.

Farrell, Daniel M. "The Justification of General Deterrence." Philosophical Review 94, no. 3 (1985): 367-94.

Farrell, Daniel M. “On Threats and Punishments.” Social Theory and Practice 15, no. 2 (1989): 125-54.

Feinberg, Joel. Offense to Others. New York: Oxford University Press, 1985.

Guanzi. The Book of Lord Shang. In Sources of Chinese Tradition, vol. 2, 2nd ed., edited by William Theodore De Bary and Irene Bloom, 192-98. New York: Columbia University Press, 1999.

Hart, H. L. A. Punishment and Responsibility: Essays in the Philosophy of Law. 2nd ed. Oxford: Oxford University Press, 2008.

Hobbes, Thomas. Leviathan, edited by C. B. Macpherson. New York: Penguin, 1978.

Kershnar, Stephen. "The Basis of Deserved Punishment is a Culpable Wrongdoing."
Jahrbuch Für Recht and Ethik/Annual Review of Law and Ethics 5 (1997): 497-513.

Kershnar, Stephen. "The Justification of Deserved Punishment Via General Moral Principles." Southern Journal of Philosophy 33, no. 4 (1995): 461-84.

Mill, John Stuart. “On Liberty.” In John Stuart Mill: On Liberty and Other Essays, edited by John Gray, 14. Oxford: Oxford University Press, 1991.

Moisescu, Christiana. 2016. "Stealing Food out of Necessity 'Not a Crime,' Italian Court Rules.” CNN, May 3. http://edition.cnn. com/2016/05/03/europe/food-theft-italy/.

Montague, Phillip. Punishment as Societal-Defense. Lanham: Rowman \& Littlefield, 1995.

Moore, Michael. Placing Blame: A Theory of the Criminal Law. Oxford: Oxford University Press, 1997.

Murphy, Jeffrie G. "Marxism and Retribution." Philosophy and Public Affairs 2, no.3 (1973): 217-43.

Nagin, Daniel S. "Criminal Deterrence Research at the Outset of the Twenty-First Century." Crime and Justice 23 (1998): 1-42.

Nagin, Daniel S. "Deterrence: A Review of the Evidence by a Criminologist for Economists." Annual Review of Economics 5 (2013): 83-105.

Peng, Qing-ren. 2009. "Putting Down the Butcher's Knife, Starting to Sell Stinking Tofu." Sina Daily News, September 15. http://dailynews. sina.com/bg/tw/twpolitics/bcc/20090904/ 2031640147.html

Quinn, Warren. "The Right to Threaten and the Right to Punish." Philosophy and Public Affairs 14, no. 4 (1985): 327-73.

Rawls, John. "Legal Obligation and the Duty of Fair Play." In Collected Papers, edited by Samuel Freeman, 117-29. Cambridge, MA: Harvard University Press, 1999.

Scanlon, Thomas. "Individual Morality and the Morality of Institutions." Filozofija I Društvo 27, no. 1 (2016): 3-19.

Shelby, Tommie. "Justice, Deviance, and the Dark Ghetto." Philosophy and Public Affairs 35, no. 2 (2007): 126-60.

Tiwald, Justin. "Punishment and Autonomous Shame in Confucian Thought." Criminal Justice Ethics 36, no. 1 (2017): XXX. 
Tadros, Victor. The Ends of Harm: The Moral Von Hirsch, Andrew. Censure and Sanctions. Foundations of Criminal Law. New York: Oxford: Clarendon Press, 2003.

Oxford University Press, 2011.

\section{ORCID}

Hsin-wen Lee (®) http://orcid.org/0000-0001-8970-9451 